\title{
Education and Economic Growth in Bangladesh- An Econometric Study
}

\author{
Md. Raihan Islam* \\ * Assistant Professor of Economics, Officer on Special Duty, Directorate of Secondary and Higher Education, \\ Dhaka \& Ph-D. Fellow, Institute of Bangladesh Studies, Rajshahi University, Bangladesh.
}

\begin{abstract}
Education is one of the fundamental important factors of economic growth. No country can achieve sustainable economic growth without substantial investment in human capital i.e. education. It improves the quality of lives and leads to broad social benefits to individuals and society. In this paper, the short and long run causal relationship between education and economic growth in Bangladesh is examined, using annual time series data covering the period from 1973 to 2010 in Bangladesh. The improved econometric methodologies; unit root and cointegration test, Granger Causality test, and Error Correction Modeling approach are applied. The stationarity of the data have been examined by using Augmented Dickey-Fuller (ADF) test. Results from Augmented Dickey-Fuller test show that both economic growth and components of educational expenditures are non stationary at the level but found stationary at the second differences, indicating that they are integrated of order two. Johansen maximum likelihood method is applied for testing long run relationship of the data. Both Eigen value and trace tests, without a trend and with a trend leads to the same results; there is one cointegrating relation at the 0.05 level of significance between education and Gross Domestic Products. Results show that there is unidirectional causality from GDP to education. As the long run relationship between education and economic growth is found. Therefore, spending on education can further help to improve economic growth. The implication of the result is that the role of education as an independent stimulus on GDP growth is not only for the long run but also for the short run. The Granger Causality test supports the results. The relationship between educational expenditure and economic growth is positive and statistically significant. One of the important findings of the study is that there is uni-directional causality between educational expenditure (proxy of education) and GDP volume (proxy of economic growth). Because, GDP causes education but education does not cause GDP to grow in Bangladesh.

Key Words: Education, Expenditure, Economic Growth, Human Development, Regression Model, Unit Root, Cointegration, Error Correction Modeling, Granger Causality.
\end{abstract}

\section{Introduction}

Education is one of the key elements of human resource. It is also one of the principal sources of increased economic growth, development and enhanced welfare of an individual and a household in the process of economic transformation. Increased labour productivity, effective use of land and other physical assets and improved socio economic empowerment are three important routes through which education can contribute to economic development.

The role of education in economic growth and their inter-relationship are increasing focus of public debate since the era of Plato. Investment in education leads to the formation of human capital, comparable to physical capital and social capital, and that makes a significant contribution to economic growth (Dickens, 2006; Loening, 2004; Gylfason and Zoega,2003; Barro, 2001). Education as an investment secures returns in the form of skilled manpower that gears the needs of development, both for accelerating economic development and for improving the quality of the society (Yogish, 2006).

Denison (1967) is one of the first to lay importance on investing in education, which is thought to have impact on growth and development. Investment in education can enhance growth and development by encouraging activities that can help catch up with foreign technological progress (Berthelemy and Varoudakis, 1996). Habib and Spiegel (1994) found that improved level of education positively affected growth in Chinese Taipei while Berthelmy (1996) came out with a different result. Francis and Iyare (2006) found evidence of bidirectional causality for Jamaica and evidence of causation running from income to education for Barbados and Trinidad and Tobago. So, it can be said that empirical results on causality between education and growth have been mixed but more results, based on improved methodology (Augmented Dickey-Fuller test, PhillipsPeron tests for unit root problem, Cointegration test, Error Correction Modeling and Granger Causality test), can help to clear the issue.

Educational expenditures in Bangladesh have been increasing since the independence in 1971. In 1973 total educational expenditure was Tk. 73 core which rose to Tk. 1330 core, Tk. 4273 core and Tk. 20470 core in 
1990, 2000 and 2008 respectively. Gross Domestic Product (GDP) has also been rising since independence. In 1974, Gross Domestic Product was Tk. 7575 core which rose to Tk. 73757 core, Tk. 237086 core, and Tk. 54,1919 core in 1990, 2000 and 2008 respectively. It is evident that both GDP and educational expenditures have been rising over the years. Therefore, it is worthwhile to asses whether educational expenditures cause GDP to grow or GDP causes education to grow or they cause each other to grow.

It is worthwhile to mention two things. Most of the earlier studies involved developed economies, while this study is in a developing economy that has seen considerable and steady increase in the expenditure on education. It is necessary to see whether the results of this study can differ from those obtained for the developing economies. Under these circumstances, education should be looked upon not as a mere item of consumption but as an investment in economic growth.

\section{Practical Scenarios of Education and GDP Growth in Bangladesh}

Bangladesh is one of the most densely populated countries in the world. It has a large number of populations with about 16 cores. Every year about $30 \%$ students are dropping out from the school. The literacy rate in Bangladesh is lower than any other developed countries of the world.

The major part of Bangladesh is rural which indicates that our economy is agriculture based. Especially, basic education can improve the capacity of individuals to live a decent life and to escape from the hunger trap. The basic idea is that being educated improves rural people's capacity to diversify assets and activities, to have access to information on health and sanitation, to enhance human capital in addition to increasing productivity in the agricultural sector; these are all essential elements to ensure food security in the long- run. Education in every sense is one of the fundamental factors of development. No country can achieve sustainable economic development without substantial investment in human capital. Education enriches people's understanding of himself and the world. It improves the quality of their lives and leads to broad social benefits to individuals and society. Education raises people's productivity and plays a very crucial role in securing economic and social progress and improving income distribution.

In Bangladesh, very few attempts have been made to study the relationship between the level of education and level of national income and the contribution of education on social change in the long run. Developed countries have a cent percent of educational attainments and their economic growth is above $10 \%$, whereas it is only 5.88 $\%$ in 2009 in Bangladesh.

UNESCO (2009) publishes a report on education and GDP relationship in Bangladesh. As expenditures on education increase, it raises GDP in the long run. In 1975, educational expenditure is $1.1 \%$ and stands to $0.94 \%$ of the GDP in 1980. In 1999, as expenditures increase to $2.42 \%$, GDP rises to Tk. 2370.9 billion. In 2001, an educational expenditure goes to $2.46 \%$ when GDP goes to 2732.0 billion. GDP again stands to Tk. 4724.8 billion as educational expenditure remains at $2.46 \%$ of GDP in 2006. At the similar fashion, the educational expenditure stands to $2.39 \%$ of GDP and GDP rises to TK. 6149.4 billion in 2010 (BANBEIS 2011). The report concludes that in spite of increasing pattern of GDP, the percentage of GDP in educational expenditures is not increased at the same tandem in Bangladesh.

In recent years, Bangladesh has made significant progress in the education sector, since it achieved a primary enrolment rate of over 92 percent and gender parity at both primary and secondary levels. Now it is important to analyze whether there is short and long run causal relationship between educational expenditures and economic growth in Bangladesh. In this context, data on educational expenditure (Total, Revenue and Development) and GDP of Bangladesh (1973-2010) have been analyzed.

\section{Impact of Education on GDP in Bangladesh}

There are five basic types of education in Bangladesh, namely: general education, madrashah education, technical- vocational education, professional education and teacher's education. Of these types, the general education is taken by majority of students ( 8.77 million) followed by madrashah ( 1.77 million) and the lowest share of enrolment is reported for the teacher's education. Considering different levels of education, junior secondary level recorded the highest enrolment with 6.23 million (57.29\%) followed by secondary level with 2.87 million (26.39\%) while the masters level reported the lowest enrolment with 75275 students. This is understandable since the masters level of education is the highest level where the education is most expensive and the requirements are stiff for anybody seeking admission to the level. (BANBEIS, Final Report-2005).

In 2006, the number of primary schools (public and private) increase about two times compare to the number of such schools in 1980. It is also remarkable that the number of female teachers has been increased from 1990's and the participation of girls' students has been increased almost double in 2006, while it becomes only about $31 \%$ in 1990 . The substantial progress has been made in improving the access of children to primary education. 
Enrolment increased from 12.6 million in 1991 to 18.4 million in 1998. In Bangladesh, total number of educational institutions is $1,16,833$ in 2008 , out of them 82,218 (of them 38,000 public) are primary level schools, 18,756 are secondary schools, 3,116 are madrasah educational institutions, 3,277 are colleges and 82 are universities. Total number of teachers for primary schools is $3,65,925$, for secondary school is $2,09,496$, for madrasah is $1,05,545$, for colleges 87,715 , and for universities is 12,585 . The number of students for primary schools is $1,60,01605$, for secondary schools is $68,19,748$, for madrasah is $18,96,111$, for college education is $18,55,633$ and for university education is $3,87,433$. These are going to increase gradually day by day.

Enrolment rate significantly varies by socio- economic groups as well. A sizeable number of children from very poor households were never enrolled in primary schools, and many of those enrolled dropped out before completing the full five year as their families depended on child labour for survival. Although there has been some reduction in drop out rate from 38 percent in 1995 percent to 35 percent in 1998, it still remains considerably high, and needless to mention that drop out rate is significantly higher amongst children from poorer households.

The above description gives an idea about growth of number of schools, teachers and students of different levels of educational institutions in Bangladesh. In view of this increasing trend, researchers are interested to see whether there exist any causal relationships between education expenditures and GDP growth or not.

\section{Objectives of the Study}

The central focus of this paper is to show the causal relationship between education and economic growth, yet the main objective of this study is to find whether there is a link between educational expenditures and Gross Domestic Product in Bangladesh in the short and long run. The specific objectives of this study are to:

1. examine the short-run stability of educational expenditures and GDP in Bangladesh;

2. show the short and long run cointegrated relationship between education and economic growth;

3. analyze causality between education and economic growth;

4. provide some policy suggestions for policy makers.

\section{Literature Review}

Only after reviewing the related literature, a researcher can answer the question of what information is already available and what the knowledge- gap is. For this, it studies a number of research works on supporting the relationship between education and economic growth. These are as follows:

The interrelation between education and economic growth has been discussed since ancient Greece. Adam Smith (1776) and the classical economists emphasized the importance of investment in human skills. Denison (1967) lays importance on investing in education for the first, which is thought to have impact on growth and development. Investment in education can enhance growth and development by encouraging activities that can help catch up with foreign technological progress (Berthelemy and Varoudakis, 1996). Benhabib and Spiegel (1994) find that improved level of education positively affected growth in Chinese Taipei. Francis and Iyare (2006) find evidence of bidirectional causality for Jamaica and evidence of causation running from income to education for Barbados and Trinidad and Tobago. Barro (1997) focuses in human capital as a determinant of economic growth. Although human capital includes education, health and aspects of 'social capital'- the main focus of the study is on education.

Gylfason and Zoega (2003) show that education has been one of the key determinants of economic growth around the world since 1965. Stevens and Weale (2003) provide a survey work on the link between education and economic growth. Teles and Andrade (2004) show the main objective of their paper is to visualize the relation between government spending on basic education and the human capital accumulation process, observing the impacts of this spending on individual investments in higher education and on economic growth. Loening (2005) investigates the impact of human capital on economic growth in Guatemala during 1951-2002 using an error- correction methodology. The results indicate a better educated labour force having a positive and significant impact on economic growth. Babatunde (2005) investigated the long run relationship between education and economic growth in Nigeria between 1970 to 2003 through the application of Johansen Cointegration technique and Vector Error Correction Methodology in Nigeria.

Khalifa (2008) examines the nature and direction of relationship between education expenditure as a proxy for human capital and economic growth in the six GCC economies using time series data for the period 1977-2004. Pradhan (2009) specifically investigates the causality between education and economic growth in the Indian economy during 1951 to 2001. The empirical investigation has been carried out by Error Correction Modeling (ECM). The findings confirmed that there is uni- directional causality between education and 
economic growth in the Indian economy, and the direction of the causality is from economic growth to education but there is absence of reverse causality.

Ahmad (2003) studies on the basis of house hold data on the returns to education in developing countries generally indicate higher social benefits at primary level compared to secondary and tertiary levels, Islam, Wadud and Islam (2007) use the multivariate causality analysis to examine relationship between education and growth in Bangladesh using annual time series data from 1976 to 2003. Paul (2009) states that in a developing nation like Bangladesh, economic growth is instrumental in fighting poverty and ensuring development Azad (2010) examines whether the efficiency of education can any influences on economic growth of a country. Islam and Alam (2010) state that if one has to show reasons behind economic success of the United States America in one word, that word will be "education". In the $19^{\text {th }}$ century, America led the way to universal basic education. Then, as other nations followed the suit.

\section{The Methodology}

The paper uses secondary time series data on different components of education expenditures and GDP for the period 1973 to 2010 in order to asses the long run causal relationship between education and economic growth. In some cases, primary data are used to explain the present educational condition of Bangladesh. The study is also based on review and analysis of secondary documents and literatures on budget and education. Analyses of trends and characteristics of budget on education have been made mainly in terms of share of education sector, in revenue, development and total education expenditures and national income.

It is observed that time series data used in many econometric studies create some special problems for econometrician. It is assumed that time series data are stationary. Hypotheses testing, which is based on small sample or asymptotic distributions of the data because, if this assumption is not taken in the estimation process, the traditional estimates, is no longer valid. Following this problem some approaches have been developed that are effective for estimation and specifications of time series analysis. The aim of this paper is to illustrate recently developed econometric models to overcome the non stationary in data and to explain relationship between education and economic growth. Improved econometric methodologies, Augmented Dickey-Fuller test, Phillips-Peron test for checking unit root problem, cointegration test for long run relationship, error correction modeling for short and long run dynamic adjustments, Granger Causality test for the long run causal relationship are applied to estimate the relationship.

\section{Empirical Results}

The econometric approach of this paper is based on the Autoregressive Vector (VAR). The chosen methodology is justified by the nature of the analysis performed in this study. The first step of this paper was to examine the stationary of the variables. If all the variables are stationary $\mathrm{I}(0)$, then there is no problem to estimate the coefficients using the variables with initial specification. However, most of the main macroeconomic variables are non- stationary, integrated of order higher than zero. If the series are nonstationary but cointegrated, then the estimation as an autocorrected model is admissible. If the variables are nonstationary and are not cointegrated then the specification of variables as differences is necessary. Most commonly used tests for the integration order of variables are Dicky- Fuller (DF) test, Augmented Dicky Fuller (ADF, 1979) test, Philips - Peron test (PP, 1988) and Kwiatkowski test (KPSS, 1992).

\subsection{Unit Root test}

The Augmented Dickey- Fuller test is used to test for the existence of unit roots and determine the order of integration of the variables. The tests are done both with and without a time trend. It can be seen in the table 7.1 that presence of a unit root, which indicates non-stationarity, cannot be rejected for levels of the variables at the 5\% and $1 \%$ level. It is found that the data series are non stationary at their level form. Because the ADF test statistics of their level form of the two variables are less than their respective critical values (in absolute terms). Hence, the null hypothesis of the non stationarity of the data is accepted at the 5\% level of significance. It was also found that it could not be rejected for the first difference. However, the non- stationarity problem vanished after second difference.

The results are as follows:

Table 7.1 indicates that there is a unit root problem that is, the data are non stationary at the level and it remains still at the first difference but the non-stationarity problem vanished after the second difference of the data; because the ADF statistics are greater than their critical values at 5\% level of significance and the null hypothesis of non-stationarity of the data are rejected.

Table 7.1: The Augmented Dickey-Fuller Unit Root Test Results 
Education and Economic Growth in Bangladesh- An Econometric Study

\begin{tabular}{|c|c|c|c|c|c|c|c|}
\hline \multirow{2}{*}{ variables } & lag & \multicolumn{2}{|c|}{ With an intercept but not a trend } & \multicolumn{2}{c|}{ With an intercept and a linear trend } \\
\cline { 2 - 7 } & & ADF statistic & $\begin{array}{c}\text { Critical } \\
\text { value }(1 \%)\end{array}$ & $\begin{array}{c}\text { Critical } \\
\text { value }(5 \%)\end{array}$ & $\begin{array}{c}\text { ADF } \\
\text { statistic }\end{array}$ & $\begin{array}{c}\text { Critical value } \\
(1 \%)\end{array}$ & $\begin{array}{c}\text { Critical value } \\
(5 \%)\end{array}$ \\
\hline $\mathrm{Y}$ & 1 & 2.70961 & -3.626784 & -2.945842 & 2.846272 & -4.234972 & -3.540328 \\
\hline $\mathrm{X}$ & 5 & 1.20729 & -3.653730 & -2.957110 & 1.650906 & -4.273277 & -3.557759 \\
\hline $\mathrm{X} 1$ & 6 & 0.96320 & -3.661661 & -2.960411 & 1.643314 & -4.284580 & -3.562882 \\
\hline $\mathrm{X} 2$ & 1 & 1.51713 & -3.621023 & -2.943427 & -1.307306 & -4.226815 & -3.536601 \\
\hline$\Delta \mathrm{Y}$ & 1 & 2.58860 & -3.62678 & -2.94584 & 0.379888 & -4.234972 & -3.540328 \\
\hline$\Delta \mathrm{X}$ & 1 & -1.76149 & -3.63290 & -2.948404 & 1.436342 & -4.273277 & -3.557759 \\
\hline$\Delta \mathrm{X} 1$ & 2 & 0.15421 & -3.639407 & -2.951125 & -1.435278 & -4.252879 & -3.548490 \\
\hline$\Delta \mathrm{X} 2$ & 1 & 1.95563 & -3.6289 & -2.9472 & -3.191387 & -4.2505 & -3.5468 \\
\hline$\Delta^{2} \mathrm{Y}$ & 1 & -4.89648 & -3.632900 & -2.948404 & -6.336567 & -4.243644 & -3.544284 \\
\hline$\Delta^{2} \mathrm{X}$ & 1 & -6.52924 & -3.639407 & -2.951125 & -6.554486 & -4.252879 & -3.548490 \\
\hline$\Delta^{2} \mathrm{X} 1$ & 1 & -8.30002 & -3.639407 & -2.951125 & -8.457023 & -4.252879 & -3.548490 \\
\hline$\Delta^{2} \mathrm{X} 2$ & 1 & -8.80977 & -3.639407 & -2.951125 & -8.697374 & -4.252879 & -3.548490 \\
\hline
\end{tabular}

The test is conducted using Eviews-2.1 and Eviews 5.1

Note: $95 \%$ critical value for the Augmented Dickey - Fuller statistic=-2.9665, Y= Gross Domestic Product (GDP) at Current Price, $\mathrm{X} 1=$ Revenue Expenditure (RE), X2= Development Expenditure (DE), $\mathrm{X}=$ Total Educational Expenditure (TEE), $\Delta=$ First Difference, $\Delta^{2}=$ Second Difference. Critical values (5\%) are from Mackinnon (1991). * The First Difference values are also reported as stationarity could not be achieved then. It can be said that the second difference of GDP growth and educational expenditures series do not have a unit roots problem and the variables series are stationary.

\subsection{Cointegration Results}

The Johansen's Maximum Likelihood (ML) cointegration technique is applied to explore the possibility of long run equilibrium. Cointegration test clarifies the existence of long run equilibrium relationship between the variables. Cointegration method usually uses two test statistics for testing the cointegration: the trace $\left(\mathrm{T}_{r}\right)$ test and the maximum eigen value $\left(\lambda_{\max }\right)$ test.

Since the variables Y, X, X1, X2, (GDP at constant price, Total Educational Expenditure, Total Revenue Expenditure, Total Development Expenditure) are integrated of order 2 (two), it confirms the possibility of cointegration between them. In other words, the long run equilibrium relationship between educational expenditures and the GDP can be examined. The estimated results, particularly maximum eigen-value and trace statistics, are presented in the table-7.2.1 to 7.2.3.

Results indicate that both the maximum eigen value test and trace tests give test statistics which are greater than the critical value for $r=0$. This means that the hypothesis of no cointegration is rejected and hence they are cointegrated. Results also indicate that for $\mathrm{r}<=1$, the estimated test statistics are less than their corresponding critical values. Therefore, it is said that GDP and educational expenditures are cointegrated with one cointegration vector that the trace and max eigen value test indicate that there is one cointegration eqn (s) at 5\% level. This means that GDP and educational expenditures have long-run relationships.

Table- 7.2.1 Cointegration between GDP and Total Educational Expenditures (Y, X):

\begin{tabular}{|l|l|l|l|l|l|l|l|l|l|l|}
\hline$H_{0}$ & $H_{A}$ & $\begin{array}{l}\text { Eigen } \\
\text { value }\end{array}$ & Trace stat. & $\begin{array}{l}5 \% \\
\text { crit.Value }\end{array}$ & $\begin{array}{l}1 \% \\
\text { crit.value }\end{array}$ & $\begin{array}{l}\text { Max. eigen } \\
\text { value }\end{array}$ & $\begin{array}{l}5 \% \text { crit. } \\
\text { val. }\end{array}$ & $\begin{array}{l}1 \% \\
\text { crit.val. }\end{array}$ & $\begin{array}{l}\text { Hypo } \\
\text { thesis }\end{array}$ \\
\hline $\mathrm{r}=0$ & $\mathrm{r}=1$ & 0.501555 & 36.72606 & 25.8721 & 25.0655 & 19.38704 & 14.2646 & 18.63 & None** \\
\hline $\mathrm{r}<=1$ & $\mathrm{r}=2$ & 0.276682 & 11.66062 & 12.51798 & 6.65 & 11.66062 & 12.51798 & 6.65 & Atmost $1^{* *}$ \\
\hline
\end{tabular}

The tests are performed using the software Eviews- 5.1

** denotes the rejection of the hypothesis at 0.05 level.

In table 7.2.1 the trace and max eigen-value statistics for GDP $(\mathrm{Y})$ and Total Educational Expenditure $(\mathrm{X})$ are 31.03927 and 23.35311 for the null hypothesis $\mathrm{r}=0$ both the values are greater than the critical values of 15.4947 and 20.04 at $5 \%$ as well as $1 \%$ levels of significance. Thus, the null hypothesis of no cointegration is rejected and the alternative hypothesis is accepted at both 5 and 1 percent of significance level. In the second row of the table the values of trace and max. eigen both are greater than the critical values at both 5 and 1 percent significance levels. Hence, the null hypothesis is rejected. Therefore, it is clear that there is one cointegration relations between Gross Domestic Product (GDP) and Total Educational Expenditure (X).

The results that appear in Table 7.2.1 suggest that the null hypothesis of no cointegration ( $\mathrm{HO}: \mathrm{r}=0)$ can be rejected at both $5 \%$ and $1 \%$ level of significance as trace statistics and max- eigen value are greater than their 
critical values. So, there is a stable long- run relationship between educational expenditures and Gross Domestic Product (GDP). Results also show that the null hypothesis of at most one cointegrating vectors $(\mathrm{H0}: \mathrm{r}<=0$ ) is rejected at $1 \%$ level of significance, according to both the trace and max- eigen statistics. This implies that these variables are cointegrated with one cointegrating equation.

Figure 7.2.1 Cointegrated Relations between Gross Domestic Product (Y) and Total Educational Expenditure (X)

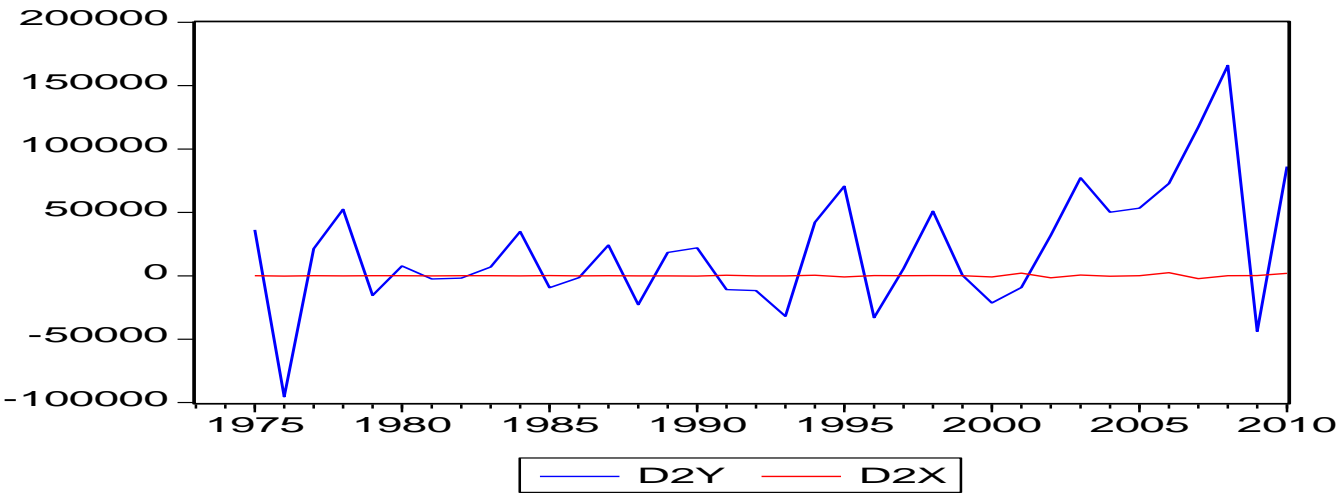

Figure 7.2.1 shows that there is two cointegrated long run relation between Gross Domestic Product (Y) and Total Educational Expenditure (X). The two lines of the figure indicate that they are moving towards the same direction. Upper line (Y) line fluctuates more but the lower line (X) line is steadier and stable that is GDP growth is increasing upper compare to total educational expenditures. The graph is drawn using the second differenced data of the respective variables.

Table 7.2.2 Cointegration between GDP growth and Total Revenue Expenditures (Y, X1)

\begin{tabular}{|l|l|l|l|l|l|l|l|l|l|}
\hline$H_{0}$ & $H_{A}$ & $\begin{array}{l}\text { Eigen } \\
\text { value }\end{array}$ & $\begin{array}{l}\text { Trace } \\
\text { stat. }\end{array}$ & $\begin{array}{l}5 \% \text { crit. } \\
\text { value }\end{array}$ & $\begin{array}{l}1 \% \\
\text { cri } \\
\text { value }\end{array}$ & $\begin{array}{l}\text { Max. } \\
\text { eigen }\end{array}$ & $\begin{array}{l}5 \% \text { crit. } \\
\text { value }\end{array}$ & $\begin{array}{l}1 \% \\
\text { crit } \\
\text { Value }\end{array}$ & Hypothesis \\
\hline $\mathrm{r}=0$ & $\mathrm{r}=1$ & 0.687557 & 43.68054 & 15.4947 & 20.04 & 41.88005 & 14.2646 & 18.63 & None** \\
\hline $\mathrm{r}<=1$ & $\mathrm{r}=2$ & 0.048784 & 1.800497 & 3.84147 & 6.65 & 1.800497 & 3.84147 & 6.65 & $\begin{array}{l}\text { At most } \\
1 * *\end{array}$ \\
\hline
\end{tabular}

The tests are performed using the software Eviews- 5.1

The trace and the max-eigen value tests indicate that there is one (1) cointegrating eqn (s) at 0.05 level. ** denotes the rejection of the hypothesis at 0.05 level.

In table 7.2.2 in the first row the trace test statistic and max-eigen values $(24.17410,17.19004)$ are greater than the critical values $(15.49471,14.26460)$ at 0.05 significance level. This means that the null hypothesis of no cointegration $(\mathrm{r}=0)$ is rejected. At the same time the second row of the table shows trace and max-eigen values $(6.984065,6.984065)$ are greater than the critical value $(6.65)$ at 0.01 significance level.

Thus, null hypothesis of no cointegration is rejected and the alternative hypothesis is accepted. Therefore, there is one cointegretad equation at 0.05 level and also one cointegrated equation in the level of 1 percent. There is one long run cointegreted relations between Gross Domestic Product (Y) and Revenue Expenditure (X1) at the 0.05 and 0.01 percent level

Figure 7.2.2 Cointegrated Relations between Gross Domestic Product (Y) and Revenue Expenditure on Education (X1)

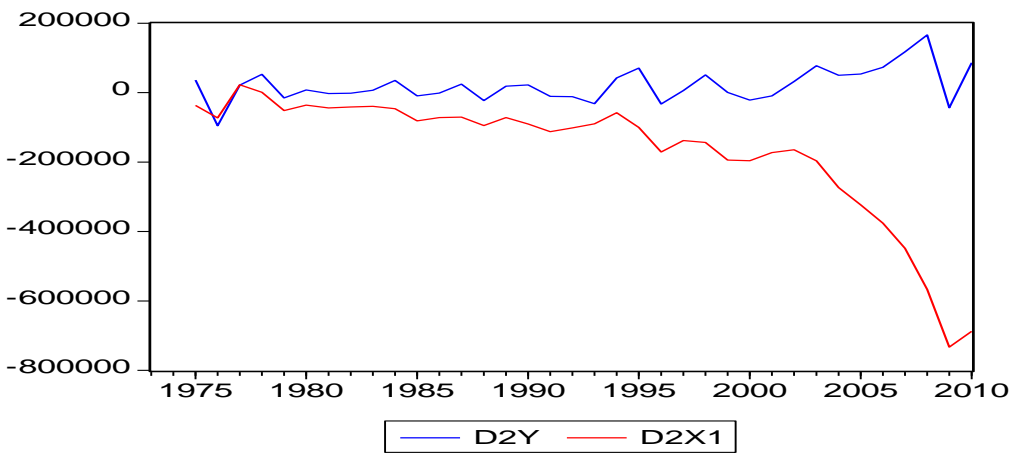


Figure 7.2.2 shows that there is two cointegrated long run relation between Gross Domestic Product $(\mathrm{Y})$ and Revenue Expenditure on Education (X1). There are high rates of fluctuation in the lines shown in the figure that indicate they are moving towards the right. Upper line $(\mathrm{Y})$ is steadier than the later one (X1). This means that revenue expenditure on education has a downward stream over the period. The graph is drawn using the second differenced data of the respective variables.

Table 7.2.3 Cointegration between GDP Growth and Total Development Expenditure(Y, X2)

\begin{tabular}{|c|c|c|c|c|c|c|c|c|c|}
\hline$H_{0}$ & $H_{A}$ & $\begin{array}{c}\text { Eigen } \\
\text { value }\end{array}$ & $\begin{array}{c}\text { Trace } \\
\text { statistic }\end{array}$ & $5 \%$ crit.value & $\begin{array}{c}1 \% \text { crit } \\
\text { value }\end{array}$ & $\begin{array}{c}\text { Max. eigen } \\
\text { value }\end{array}$ & $\begin{array}{c}5 \% \\
\text { crit.value }\end{array}$ & $\begin{array}{c}1 \% \text { crit. } \\
\text { value }\end{array}$ & Hypothesis \\
\hline $\mathrm{r}=0$ & $\mathrm{r}=1$ & 0.37879 & 19.4947 & 15.49471 & 20.04 & 17.1391 & 14.2646 & 18.63 & None** \\
\hline $\mathrm{r}<=1$ & $\mathrm{r}=2$ & 0.06153 & 2.2863 & 3.841466 & 6.65 & 2.28626 & 3.84147 & 6.65 & At most $1^{* *}$ \\
\hline
\end{tabular}

The tests are performed using the software Eviews- 5.1

The trace and the max-eigen value tests indicate that there is one (1) cointegrating eqn (s) at 0.05 level. ** denotes the rejection of the hypothesis at 0.05 level.

Results in the table 7.2.3 indicate that the trace and max-eigen values $(19.49471,17.1391)$ are greater than the critical value $(15.49471,14.2646)$ respectively at 0.05 percent level of significance. Therefore, the null hypothesis of no cointegration is rejected. Whereas in the second row both the statistic values are less than the critical value in absolute term. Thus the null hypothesis of no cointegration is accepted in both levels. Hence, there is one (1) long run relation between the Gross Domestic Product (Y) and the Development Expenditure on education (X2).

Figure 7.2.3 Cointegrated Relation between Gross Domestic Product (Y) and Development Expenditure Education (X2)

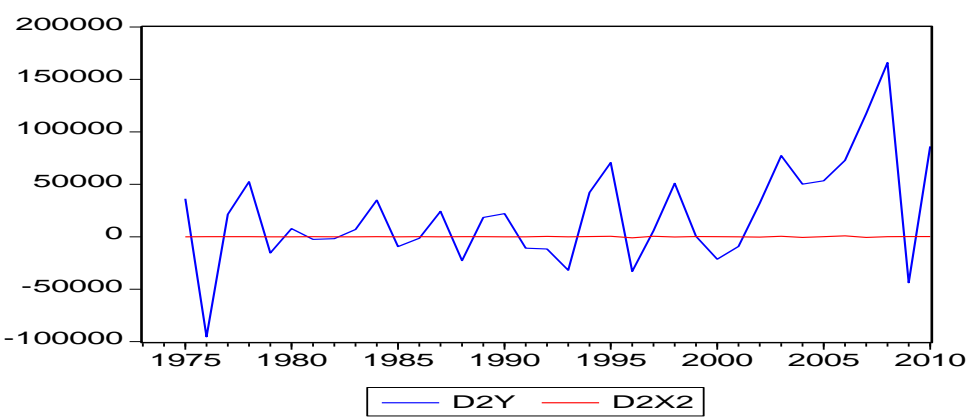

Figure 7.2.3 indicates that there is one cointegrated long run relation between the Gross Domestic Product (Y) and Development Expenditure on Education (X2). The two lines of the figure indicate that they are moving towards the right and same direction. Y line is more fluctuating with change of time but X2 line is steadier than $\mathrm{Y}$. The graph is also drawn using the second differenced data of the respective variables

\subsection{Results for Error Correction Model (ECM)}

Johansen maximum likelihood procedures are used to test for cointegration and to estimate the error correction parameters after checking unit root tests to confirm that each series is an I (1) process. Since cointegrating relationship is found between educational expenditures and GDP growth, an Error Correction Model (ECM) could be constructed to determine the direction of causality. A significant lagged ECT coefficient implies that past equilibrium errors affect current outcomes. Here it is needed to decide on what lags to choose (up to the maximum lag of 2 used in the Johansen procedure above). The long term effects of the variables can be represented by the estimated cointegration vector. If two variables are cointegrated, there must exist an Error Correction Mechanism (ECM). This indicates that error correction model is associated with the cointegration test. The estimated coefficient of error correction term shows the long term effect and the estimated coefficient of lagged variables shows the short term effect. Results of error correction model are given below;

The following Table 7.3.1 shows that the error correction term is significant for educational expenditure, total revenue expenditure and total development expenditure, indicating the long run causality from economic growth to total educational expenditure, total revenue expenditure, and total development expenditure. At the same time, the error term is insignificant for the GDP growth equation. This indicates that there is absence of long run causality between educational expenditure and revenue and development expenditures and GDP growth. There is however, the evidence of short run bi directional causality among the variables. 
Table 7.3.1 Causality test from Estimates of Error Correction Model for GDP and Educational Expenditures

\begin{tabular}{|c|c|c|c|c|c|}
\hline Variables & Lagged Y & Lagged X & Lagged X1 & Lagged X2 & EC Term \\
\hline $\mathrm{Y}$ & $\begin{array}{c}0.655134 \\
(0.12361) \\
{[5.29997]}\end{array}$ & $\begin{array}{c}0.003558 \\
(0.00181) \\
{[1.96509]}\end{array}$ & $\begin{array}{c}0.003017 \\
(0.00123) \\
{[2.44946]}\end{array}$ & $\begin{array}{c}-0.001458 * \\
(0.00055) \\
{[-2.64232]}\end{array}$ & $\begin{array}{c}-0.094554 \\
(0.02982) \\
{[-3.17039]}\end{array}$ \\
\hline $\mathrm{X}$ & $\begin{array}{c}-28.19047 \\
(22.4590) \\
{[-1.25520]}\end{array}$ & $\begin{array}{c}0.098202 \\
(0.32894) \\
{[0.29854]}\end{array}$ & $\begin{array}{l}0.432365 \\
(0.22379) \\
{[1.93198]}\end{array}$ & $\begin{array}{c}0.046333 \\
(0.10028) \\
{[0.46203]}\end{array}$ & $\begin{array}{c}5.00 \mathrm{E}-05 * * \\
(0.00044) \\
{[0.11436]}\end{array}$ \\
\hline $\mathrm{X} 1$ & $\begin{array}{c}18.31258 \\
(30.3809) \\
{[0.60277]}\end{array}$ & $\begin{array}{c}-0.603042 \\
(0.44496) \\
{[-1.35526]}\end{array}$ & $\begin{array}{c}-0.643252 \\
(0.30273) \\
{[-2.12482]}\end{array}$ & $\begin{array}{c}-0.541027 \\
(0.13565) \\
{[-3.98828]}\end{array}$ & $\begin{array}{c}0.000123 * * \\
(0.00030) \\
{[0.41543]}\end{array}$ \\
\hline $\mathrm{X} 2$ & $\begin{array}{c}-15.48329 \\
(36.2596) \\
{[-0.42701]}\end{array}$ & $\begin{array}{c}-0.508454 \\
(0.53106) \\
{[-0.95743]}\end{array}$ & $\begin{array}{c}-0.005740 \\
(0.36131) \\
{[-0.01589]}\end{array}$ & $\begin{array}{c}-0.452976 \\
(0.16190) \\
{[-2.79782]}\end{array}$ & $\begin{array}{c}-0.000535 * * \\
(0.00013) \\
{[-4.01634]}\end{array}$ \\
\hline
\end{tabular}

$*,(* *)$ denotes the rejection of the hypothesis at the $5 \%(1 \%)$ level.

Causality tests for the above variables are based on Error Correction Models in first differences. Figures in parentheses are p-values of the Wald tests for the joint significance of lagged variables, and figures in brackets are t-statistics.

\subsection{Results of Granger Causality}

Granger Causality theorem (1988) mentions that there should be at least one direction of causality between the two variables, if they are cointegrated. Accordingly, the causality model has been estimated and that has been tested by F- statistics.

Table 7.4.1 Granger Causality between the Variables (Y, X, X1 and X2)

\begin{tabular}{|c|c|c|c|c|c|}
\hline Null Hypothesis & Lag & Obs & F statistic & Probability & Decision \\
\hline X does not Granger Cause Y & 1 & 37 & 0.69744 & 0.40948 & Accepted \\
Y does not Granger Cause X & & & 29.9107 & 4.2 E-06 & Rejected** \\
\hline X1 does not Granger Cause Y & 1 & 37 & 37.1297 & 6.5 E-07 & Rejected** \\
Y does not Granger Cause X1 & & & 8.28341 & 0.00687 & Accepted \\
\hline X2 does not Granger Cause Y & 1 & 37 & 10.9380 & 0.00223 & Rejected * \\
Y does not Granger Cause X2 & & & 6.84878 & 0.01314 & Accepted \\
\hline
\end{tabular}

The tests are performed using the software Eviews-5.1

Note: $\mathrm{Y}=\mathrm{GDP}$ at constant price, $\mathrm{X}=$ Total Educational Expenditure, $\mathrm{X} 1=$ Total Revenue Expenditure, $\mathrm{X} 2=$ Total Development expenditure respectively.

Table 7.4.1 shows the results of sector wise Granger causality. Result shows that total Educational Expenditures do not Granger causes Gross Domestic product but GDP causes total educational expenditures. That is, causation goes from Gross Domestic Product to Educational Expenditures. In case of revenue expenditure, GDP does not cause revenue expenditure but revenue expenditure causes GDP at 0.05 level of significance. Development expenditure does not Granger cause GDP but GDP causes development expenditure. From this result, it can be said that the educational attainments leads to GDP growth and there is unidirectional causality between education and economic growth. Because, both variables do not cause at the same tandem.

Since, F statistic is statistically significant, the null hypothesis for total revenue expenditure, total development expenditure do not Granger cause GDP can be rejected. F statistics for total educational expenditure are insignificant. This means that total educational expenditure do not Granger cause GDP growth. This means that educational expenditures Granger cause GDP to grow.

Results reveal that there are presence of uni-directional causality between economic growth and education. That is, total educational expenditure has a very little influence on GDP in Bangladesh but GDP growth Granger cause total educational expenditure, revenue expenditure, but GDP does not Granger cause development expenditure on education in Bangladesh.

\section{Conclusion}

This paper examines the causal relationship between education and National Income (GDP) growth for Bangladesh over the period 1973- 2010 using a multivariate approach. The variables are GDP at constant price, Total Educational Expenditure, Total Revenue Expenditure, Total Development Expenditure. The relationship between economic growth and education can take three forms. GDP can cause education to grow, these can help each other to grow or education can cause GDP to grow. Results show that there is uni-directional causality running from GDP to education and vice- versa. Results from Augmented Dickey-Fuller test show that both economic growth and components of educational expenditures are non stationary at the level but found stationary at the second differences, indicating that they are integrated of order two. 
In order to test the cointegration, the maximum likelihood estimation method of Johansen and Juelius (1990 and 1995) is applied. Both Eigen value and trace tests, without a trend and with a trend leads to the same results; there is one cointegration relation at the 0.05 level of significance between education and Gross Domestic Products. Johansen cointegration results reveal that economic growth and total educational expenditures, Revenue and development expenditures are cointegrated. This indicates the existence of long run equilibrium relationship between GDP and components of educational expenditures. Granger causality test finally confirms the presence of uni-directional causality between education and economic growth. The empirical methodology adopted for this purpose includes the Granger Causality test within an error-correction framework. The findings suggest strong evidence for uni-directional causality from economic growth to education expenditure.

These results contradict many earlier studies which found bi-directional causality running either from education to growth or growth to education, but it is consistent with the prevailing situation in Bangladesh where GDP growth and educational expenditures are not working in tandem. In the area of research studying causality between education and growth, especially in the developing economy, these results can provide a bench mark of comparisons for further research work.

\section{References}

[1]. Alam, F. M. (2007) Education and Economic Growth: Lessons from Japan for Bangladesh, Adorn Public. Dhaka.

[2]. Al- Yousif, K.Y. (2008), Education Expenditure and Economic Growth; some Empirical Evidence from the GCC countries, Journal of Developing Areas, Emirates.

[3]. Azad A. S. M. S.,( 2010.) Educational Efficiency and Economic Growth- Evidence fromBangladesh, Chittagong.

[4]. BANBEIS (2010), Bangladesh Educational Statistics 2009, Ministry of Education, Government of Bangladesh.

[5]. BBS (2010) Statistical Yearbook of Bangladesh-2009, Ministry of Planning, Government of Bangladesh.

[6]. Bangladesh Economic Review 1990 to 2010; 1973-1999, GDP \& GDP (\%) estimated at fixed price on 1984-85.

[7]. Barro J. R. (1997), Determinants of Economic Growth, A cross country empirical study, MIT press, Cambridge.

[8]. Benhabib, J. and M.M. Spiegel, (1994), The Role of Human Capital in Economic Development - evidence from aggregate crosscountry data, Journal of Monetary Economics, 34(2), October.

[9]. Berthelemy, G.C. and A. Varoudakis (1996), Policies for Economic Take-off, Policy Brief no 12, OECD, Paris.BIDS (2007), Disparity in Education and Quality Education for all, Bangladesh Institute of Development Studies, Dhaka.

[10]. Chakrawarty, B (2005), Human Capital, Education Policy and Economic Growth, Productivity, 46 (1), 13-20. New Delhi.

[11]. Dahlin B.G. (2005), The Impact of Education on Economic Growth: Theory, Findings an Policy Implications. Working Paper, Duke University.

[12]. Dhesi, S. A. (1979), Human Capital Formation and Utilization, Sterling Publishers Private Limited, New Delhi.

[13]. Dickey, D. and Fuller, W.A. (1981), Likelihood Ratio Statistics for Autoregressive Time Series with Unit Root, Econometrica, 49, 1057-1072.

[14]. Frances, B. and S. Iyare (2006), Education and Development in the Caribean; a cointegration and causality approach, Economics Bulletin, 15 (2), 1-13.

[15]. Ghosh, B. N. (2007), Population Economics: An Analysis of Human Resource Development, Deep and Deep Publications, New Delhi.

[16]. Granger, C.W.J.(1986), Development in the Study of Cointegrated Economic Variables, Oxford Bulletin of Economics and Statistics, 48, 213-228.

[17]. Gujarati D. N. (1978), Basic Econometrics, first edition, Tata McGraw-Hill Publishing Company Limited, New Delhi

[18]. Gujarati D.N.(1995), Basic Econometrics, $4^{\text {th }}$ Edition, Tata Mcgraw Hill Publications, New York.

[19]. Gylfason T. and G. Zoega (2003), Education, Social Equality and Economic Growth; A View of the Landscape, Stockholm.

[20]. Hanushek. E..A. and L. Wobmann (2008), Education and Economic Growth; Chapter prepared for the International Encyclopedia of Education, $3^{\text {rd }}$ Edition. Stanford.

[21]. Hanushek A. Eric and Wobmann L. (2008), Education quality and Economic Growth, International Bank for Reconstruction and Development, 1818 H Street, New York.

[22]. Islam N. M. (2011), An Introduction to Research Methods: A Hand Book for Business and Health Research, Second Edition, Mullick \& Brothers Publications, Dhaka.

[23]. Saiful T. I, A.Wadud and Q. Islam, (2007) "Relationship between Education and GDP Growth; a multivariate causality analysis for Bangladesh." Economics Bulletin, Vol, 3 No.35 pp 1-7.

[24]. Johansen.S. and K. Juselius (1990), Maximum Likelihood Estimation and Inference on Cointegration with Application to the Demand for Money. Oxford Bulletin of Economic Review, 10 (1).

[25]. Jorgenson, H. \& M. Fraumeni, (1998), Investment in Education and U.S Economic Growth. Netherlands: Kluwer Academic Publishers.

[26]. Li, H. and H. Liang (2009), Health, Education and Economic Growth in East Asia, Satin, Honkong.

[27]. Kothari, C. R. (2010), Research Methodology: Methods and Techniques, Second Edition, New Age International Publishers, New Delhi.

[28]. Mackinnon, K.G.(1991), Critical Values for Cointegration Tests, Oxford University Press, London.

[29]. Nath S.R. (2010), Qualitative Methods in Educational Research, Academic Press and Publishers library, Dhanmondi, Dhaka.

[30]. Rusidan, R. I. (2007), Discrimination in Education and Quality Education for All, Bangladesh Institute of Development Studies, Dhaka.

[31]. Schultz, T. (1988), Education, Investment and Rreturns, In handbook of development economics. The Netherlands: North Holland.

[32]. Sheffrin, S., \& R. Triest, (December, 1995), A new approach to causality and economic growth, Working paper series, No 95-12, Federal Reserve Bank of Boston.

[33]. Todaro M.P(1992). Economic Development in the Third World, Fourth Ed. Longman Group Ltd. New York.

[34]. UNDP (1996), Human Development in Bangladesh, A Pro-poor Agenda: Disaggregated Profile of Human Development Indicators , Volume-2, Orchid Printers, Dhaka.

[35]. V. K. Teles and J. D. Andrade (2004), Public Investment in Basic Education and Economic Growth, Sao Paulo.

[36]. World Bank (2000), Bangladesh Education Sector Review: Volume-II, The University Press Limited, Dhaka. 